\title{
Identification and characterization of lactic acid bacteria isolated from some medicinal and/or edible Philippine plants
}

\author{
*Saguibo, J.D., Mercado, M.A., Maldia, S.T., Jimeno, B.T., Perez, M.T.M., Calapardo, \\ M.R. and Elegado, F.B. \\ National Institute of Molecular Biology and Biotechnology (BIOTECH), University of the Philippines Los \\ Baños, College, Laguna 4031 Philippines
}

\begin{abstract}
Article history:
Received: 5 April 2019

Received in revised form: 5

May 2019

Accepted: 11 May 2019

Available Online: 21 May

2019

Keywords:

Edible plants,

Antibiotic resistance,

Antimicrobial activity,

Lactic acid bacteria,

Medicinal plants,

Probiotics
\end{abstract}

DOI:

https://doi.org/10.26656/fr.2017.3(6).148

\begin{abstract}
Probiotics research on lactic acid bacteria (LAB) continues to be paramount in the development of nutraceutical or functional foods. In this study, 47 selected Philippine plants having nutritional (edible such as vegetables) and/or medicinal values (therapeutic), were collected, from which selected fruit and leaves were subjected to LAB enumeration. Among these, $46.7 \%$ plant leaves reported to have strong antimicrobial property resulted in non-isolation of LAB while edible plant leaves with less or no antimicrobial properties generally gave numerous $\mathrm{LAB}$ isolates. Isolates coming from ripened guava (Psidium guajava L.), lobo-lobohan or cape gooseberry (Physalis peruviana L.) fruit, parsley (Petroselinum crispum), pandan (Pandanus amaryllifolius), spinach (Spinacea oleracea), leek (Allium ampeloprasum var. porrum) and niyog-niyogan (Quisqualis indica L.) leaves were identified through partial $16 \mathrm{~S}$ rRNA analysis and tested for probiotic properties. Overall, Streptococcus luteciae Lb17 from ripe gooseberry fruit exhibited the highest antimicrobial activities against Staphylococcus aureus BIOTECH 1526, Escherichia coli O157: H7 BIOTECH 10311 and Bacillus cereus BIOTECH 1509. On the other hand, Enterococcus hirae (H and S63) from stevia were susceptible to streptomycin at minimum inhibitory concentration or MIC of $128 \mathrm{ug} / \mathrm{mL}$ ). Lactobacillus plantarum F39 and all the other strains tested, meanwhile, was susceptible to ampicillin at MIC of $2 \mathrm{ug} / \mathrm{mL}$ and $0.125 \mathrm{ug} / \mathrm{mL}$. Results were lower or equal to the established cut off value indicating the absence of antibiotic resistance genes among the identified strains, except for Pediococcus (Par5 and NN39) which showed resistance against streptomycin. Further investigation is needed to rule out the possibility of transfer of antibiotic resistance to pathogens present in the gut. All isolates tested were able to survive at artificial gastric juice ( $\mathrm{pH} 2)$, revived at the simulated intestinal fluid ( $\mathrm{pH} 8$ ), and exhibited minimal titratable acidity and diacetyl production. For genetic screening of plantaricin genes, F39 possesses both plantaricin EF and plantaricin J, while Lactobacillus fermentum F36 has plantaricin EF. Both isolates were subjected to DNA fingerprinting. Such findings on the local isolates' probiotic properties suggest the possibility of incorporating them into different plant-based probiotic foods.
\end{abstract}

\section{Introduction}

The application of probiotics continues to evolve due to its profound importance. This is particularly pertinent in terms of its use in developing health products.

Fuller (1989) defines probiotics, including lactic acid bacteria (LAB), as live microbial feed supplements which beneficially affect the host animal by improving its intestinal microbial balance. $\mathrm{LAB}$ remain to be a crucial topic for research as its link on health and nutritional benefits are far more relevant today with the increasing demand for plant-based probiotic foods and nutraceutical commodities.

It was at the beginning of the $20^{\text {th }}$ century when Nobel Prize-winning Russian scientist Elie Metchnikoff first proposed the significance of Lactobacillus, a probiotic strain. He suggested that the long, healthy life of Bulgarian peasants resulted from their consumption of fermented milk products. Since then, many claims relating to probiotic properties have been made varying from the prevention of infectious diseases (Rolfe, 2000), 
curing of irritable bowel syndrome, alleviation of allergies, digestion of lactose and lowering of serum cholesterol levels (Anderson et al., 2001) to the prevention of cancer (Gibson and MacFarlane, 1994). Today, aside from its inclusion to dairy products, probiotics have similarly been incorporated into nondairy products including plants, plant parts or their extracts. This is in line with the increasing number of those shifting to vegetarianism and the large number of individuals who are lactose intolerant (Furtado Martins et al., 2013). It is, therefore, crucial to continuously identify additional possible means to isolate other probiotic strains, particularly from medicinal and/or edible plants.

The Philippines is a tropical country endowed with very rich biodiversity including those plants having nutritional and/or medicinal use. A medicinal plant is defined by WHO, as any plant which, in one or more of its organ, contains substance that can be used for therapeutic purpose or which is a precursor for the synthesis of useful drugs (Gopal, et al. 2014). On the other hand, edible plants include plants with parts that are safely consumed as food by humans. Examples are the vegetables which refer to edible plants, commonly collected and/or cultivated for their nutritional value for humans (Kuete, 2017). Most often, the botanical definition of vegetables is the "edible part of the plant" (Agudo, 2005). Other obvious examples are the edible fruit-bearing trees.

Some plants are both edible, having nutritional properties and medicinal, having therapeutic purpose. Recent estimates suggest that over 9,000 plants have known medicinal applications in various cultures and countries (Farnsworth and Soejarto, 1991). Some of these medicinal plants are extensively studied, such as guava (Psidium guajava L.), moringa (Moringa oleifera) and lagundi (Vitex negundo).

It is with this high potential of determining other further uses of novel Philippine isolates that continued efforts on LAB isolation from fermented foods, animal gut, and herbage or plants (Saguibo and Elegado, 2012) have been done. This study, in particular, is aimed to isolate and identify potential LAB from different Philippine plants to determine their probiotic properties and assess the possibility of incorporating them into nondairy plant-based functional products.

\section{Materials and methods}

\subsection{Isolation and purification of lactic acid bacteria from herbal plants}

A total of forty-seven plant samples were collected from different sites within the municipality of Los
Baños, Laguna, Philippines. Plant parts such as leaves and fruit were washed with tap water and rinsed with sterile distilled water prior to fermentation in sterile flask covered with cotton plug. Fruits were chopped into small cubes (about $1 \mathrm{~cm}^{3}$ ) using clean knife and chopping board while leaves were cut into small pieces (about 1 $\mathrm{cm}^{2}$ ) using clean scissors. Samples weighed $10 \mathrm{~g}$ were blended with $90 \mathrm{~mL}$ sterile $0.1 \%$ peptone for $1 \mathrm{~min}$. After 1-2 days incubation at $37^{\circ} \mathrm{C}$, it was serially diluted and pour-plated on De Mann Rogosa and Sharpe (MRS), Pronadisa Madrid, Spain, agar containing $1 \% \mathrm{CaCO}_{3}$. The plates were incubated in an air-tight candle canister at $37^{\circ} \mathrm{C}$ for $48 \mathrm{hrs}$. Presumptive LAB colonies with clearing were purified by repeated streak plating using the same agar medium until pure colonies were obtained. Gram staining and catalase test were also performed.

\subsection{Characterization of probiotic properties}

\subsubsection{Antimicrobial activity assay}

The antimicrobial activity of presumptive LAB isolates was tested against standard indicators which are also common food pathogens, namely Escherichia coli Ec2, Escherichia coli O157: H7 BIOTECH 10311, Salmonella enterica serovar Typhimurium BIOTECH 1826, Staphylococcus aureus Sa16 BIOTECH 1526, Bacillus cereus BIOTECH 1509 and Listeria innocua NB5, using dual agar overlay method. Quantification of the zones of inhibition as a measurement of antimicrobial activity was conducted following the method of dual overlay agar by Muhialdin et al. (2012) with some modification. A known number of LAB cells were spotted onto MRS agar plate. After 18-24 hrs incubation at $37^{\circ} \mathrm{C}$, it was overlaid with Nutrient Agar containing the test pathogen. Zones of inhibition of three replicates were thereafter measured and recorded. Antimicrobial activity $\left(\mathrm{mm}^{2} /\right.$ cell $)$ was mathematically expressed following the formula $\Pi^{2}$ /total spotted LAB count.

\subsubsection{Antibiotic susceptibility test}

Antibiotic susceptibility test was done by replica plating the LAB isolates in different concentrations of streptomycin (Boehringer Mannheim, Germany) and ampicillin (Boehringer Mannleim, Germany), following the method of Wiegand et al. (2008) but with modifications. Active overnight cultures grown in MRS broth were resuspended in $6 \mathrm{~mL}$ saline solution for turbidity assessment by OD reading at $625 \mathrm{~nm}$ (UV1800 Spectrophotometer, Shimadzu Corp., Kyoto, Japan). The absorption of each cell suspension was adjusted to the range of 0.08 to 0.13 which approximately yields $1 \times 10^{8}$ $\mathrm{CFU} / \mathrm{mL}$. Dilutions of ten-fold of the cell suspensions were prepared by adding $10 \mu \mathrm{L}$ in $90 \mu \mathrm{L} 0.9 \%$ saline placed in the wells of a sterile 96-well microtiter plate. From the same bacterial suspension, $10 \mu \mathrm{L}$ was obtained 
for serial dilution for actual plating and another $10 \mu 1$ was added to microtiter plate.

The antibiotic-containing agar plates were carefully prepared by allotting $25 \mathrm{~mL}$ MRSA medium per plate and adding calculated volumes of the antibiotics to obtain the recommended range of concentrations (Final concentrations in agar were $0.125,0.25,0.5,1,2,4,8$ $\mu \mathrm{g} / \mathrm{mL}$ ampicillin and $2,4,8,16,32,64,128,256 \mu \mathrm{g} / \mathrm{mL}$ streptomycin). A 48-pin replicator was alcohol and heatsterilized and allowed to cool down on a fresh MRSA plate without antibiotic. Inoculations were done by dipping the pins in the diluted cell suspensions and transferring in the MRSA plates, first in the control plate without antibiotic then in plates containing antibiotic with the lowest concentration to the highest concentration. The inoculations were done in duplicates. The inoculum spots were allowed to dry inside the biosafety cabinet and the plates were incubated at $37^{\circ} \mathrm{C}$ for 40-48 hrs then observed for presence or absence of growth. The absence of growth indicates susceptibility of the tested LAB isolates to that particular antibiotic concentration.

\subsubsection{Acid and bile tolerance}

The acid and bile tolerance of LAB was determined using artificial gastric juice ( $\mathrm{pH} 2.0$ ) and simulated intestinal fluid $(\mathrm{pH} 8.0)$ based on the procedure by Fernandez, Boris and Barbes (2003). Colony counts were obtained at the initial time. After a three-hour exposure to each of the artificial fluids, these were incubated at $37^{\circ} \mathrm{C}$ for $24-48 \mathrm{hrs}$ using MRS agar. The percent survival was thereafter computed by dividing the final over the initial colony count multiplied by 100 . The highest percent survival was considered the most tolerable.

\subsubsection{Titratable acidity}

The LAB isolates were separately inoculated to $9 \mathrm{ml}$ $10 \%$ skim milk and incubated at $37^{\circ} \mathrm{C}$ for 24 hours. Two to three drops of $1 \%$ phenolphthalein indicator were added. Samples were titrated using standardized $0.1 \mathrm{~N}$ $\mathrm{NaOH}$ until a faint pink color was obtained. The volume of $\mathrm{NaOH}$ used was recorded and percent titratable acidity was computed as follows:

$$
\% \mathrm{TA}=\frac{\left.\left[\mathrm{N}_{\mathrm{NaOHX}} \mathrm{V}_{\mathrm{NaOH}} \mathrm{H}\right] \times\left[\frac{\left.\mathrm{MW}_{\text {lactic acii }}\right]}{1000}\right] \times 100\right]}{\mathrm{V}_{\text {sample titrated }}}
$$

Where $\mathrm{V}_{\mathrm{NaOH}}=$ Volume of $\mathrm{NaOH}$ used in titration; and $\mathrm{MW}_{\text {lactic acid }}=$ molecular weight of lactic acid, $90 \mathrm{~g} / \mathrm{mol}$

\subsubsection{Diacetyl test}

An amount of $10 \mathrm{mg}$ of creatine (Sigma Aldrich) and $2 \mathrm{~mL}$ of $40 \% \mathrm{NaOH}$ was added to $2.5 \mathrm{~mL}$ test culture (18-24 hrs old). The mixture was allowed to stand until color formation was observed. Formation of red color at the surface indicated the presence of diacetyl and color intensity relative to the quantity of diacetyl compounds present in the sample.

\subsubsection{Identification of isolates by partial 16s r-RNA gene sequencing}

Amplification was carried out using universal $\begin{array}{lllll}\text { primers } & \text { FC27 } & \text { sense } & \left(5^{\prime}\right. & \text { AGAGT }\end{array}$ TTGATCCTGGCTCAG 3') and RC1492 antisense (5' TACGGCTACCTTGTTACGACTT $3^{\prime}$ ), and using a thermocycler (PTC-100 ${ }^{\mathrm{TM}}$, Programmable Thermal Controller, MJ Research, Inc., Watertown, MA 02172, USA) following the reaction mix and amplification parameters. The PCR amplicons obtained were purified using DNA purification kit, (PureLink, PCR purification kit Invitrogen, CA, USA) and sent to Macrogen Inc., Korea for DNA sequencing. Meanwhile, sequence similarity searches were performed using the Basic Local Alignment Search Tool Nucleotide (BLASTN) program from the National Center for Biotechnology Information (NCBI), USA GenBank database.

\subsection{Genetic screening of plantaricin gene}

Amplification of plantaricin genes were carried out in $25 \mu 1$ reaction volume consisting of $1 \mathrm{x}$ PCR buffer buffer [50 mM KCl, $20 \mathrm{mM}$ Tris- $\mathrm{HCl}(\mathrm{pH} \mathrm{8.4)],} 2 \mathrm{mM}$ $\mathrm{MgCl}_{2}, 200 \mu \mathrm{M}$ each of dNTPs, 50 pmoles of each primer (plnEF-F 5'GGCATAGTTAAAATTCCCCCC 3'; plnEF-R 5'CAGGTTGCCGCAAAAA AAG 3'; plnJ -F 5'TAACGACGGATTGCTCTG 3'; plnJ-R 5'AATCAAGGAATTATCACATTA GTC 3'), 1U of Taq DNA polymerase (Invitrogen Life Technologies, Carlsbad, CA USA) and $50 \mathrm{ng}$ of template DNA. The amplification parameters were as follows: $94^{\circ} \mathrm{C}$ for 3 $\mathrm{min}$, followed by 30 cycles of $1 \mathrm{~min}$ at $94^{\circ} \mathrm{C}, 1 \mathrm{~min}$ at $53.2^{\circ} \mathrm{C}$ [pln EF] or $52^{\circ} \mathrm{C}$ [plnJ] and 1 min at $72^{\circ} \mathrm{C}$, with a final extension of 10 mins at $72^{\circ} \mathrm{C}$. Duplicate reactions were carried out for DNA sequencing.

Meanwhile, the amplified products were detected by gel electrophoresis in $1 \%$ agarose gels at 100 volts. The molecular weight standard $1 \mathrm{~kb}$ plus DNA ladder (Invitrogen Life Technologies Inc.) was included for size estimation of amplified fragments. The molecular weights of all amplicons generated were determined using Labworks Image Acquisition and Analysis software (UVP Inc., Upland, CA USA).

\section{Results}

3.1 Isolation and purification of lactic acid bacteria from herbal and plants

$\mathrm{LAB}$ is naturally found in dairy products, grain products, meat and fish products, water, fruit and fruit 
juices, pickled vegetables and sour dough. By nature, all plant surfaces contain lactobacilli in low numbers along with other LAB strains in many decaying plant materials, especially decayed fruits. Prominently isolated species from different plant sources are $L b$. plantarum, $L b$. brevis, Lb. coryniformis, Lb. casei, Lb. curvatus, Lb. sake, Lb. fermentum (Kandler, 1984). Despite the reported antimicrobial properties of some leaf extracts against common pathogens such as Escherichia coli, Salmonella enterica serovar Typhi, Staphylococcus aureus, Proteus mirabilis, Shigella dysenteria, Streptococcus spp., Sarcina lutea and Mycobacterium phlei (Joseph and Priya, 2011), it is interesting to note that some LAB strains have profound resistance against leaf extract antimicrobials. The isolation of lactics $L b$. fermentum $\mathrm{F} 36$ and $L$ b. plantarum $\mathrm{F} 39$ have already been reported by Saguibo et al. (2012). Based on several experiments conducted, a total of 47 Philippine plants and herbs were used to isolate $\mathrm{LAB}$ in this study, from which $46.7 \%$ resulted in non-isolation of LAB. These plants, shown in Table 1, are reported to have antimicrobial properties. On the other hand, plants which are edible or possess less antimicrobial property resulted in the isolation of LAB (Table 2).

Table 1. Selected Philippine plant leaves without isolated lactic acid bacteria.

\begin{tabular}{|l|}
\hline Ashetaba (Angelica keiskei) \\
\hline Acapulko (Cassia alata) \\
\hline Ampalaya (Momordica charantia) \\
\hline Aratiles (Muntingia calabura) \\
\hline Atis (Annona squamosa Linn.) \\
\hline Avocado (Persea americana) \\
\hline Banaba (Lagerstroemia speciosa) \\
\hline Cape gooseberry (Physalis peruviana) \\
\hline Cassava (Manihot esculenta) \\
\hline Duhat (Syzygium cumini) \\
\hline Garem-garem (Achyranthes aspera) \\
\hline Guyabano (Annona muricata) \\
\hline Guava (Psidium guajava L) \\
\hline Ikmo (Piper betle) \\
\hline Kakawate (Gliricidia sepium) \\
\hline Lagundi (Vitex negundo) \\
\hline Lobo-lobohan (Physalis peruviana L.) \\
\hline Malunggay (Moringa oleifera) \\
\hline Mango (Mangifera indica) \\
\hline Sambong (Blumea balsamifera) \\
\hline Takip-kuhol (Centella asiatica L.) \\
\hline Tawa-tawa (Euphorbia hirta) \\
\hline Ulasimang bato or pansit-pansitan (Peperomia pellucida \\
Linn.) \\
\hline
\end{tabular}

LAB strains that are innately present on the surface of the plant do not go away easily by washing as that of the transient bacteria. Given appropriate medium, both the innate and some of the left transient bacteria and also yeast will grow together. The use of MRSA supplemented with calcium carbonate will differentiate lactic acid bacteria.

Table 2. Selected Philippine plant leaves with isolated lactic acid bacteria.

\begin{tabular}{|c|}
\hline Alugbati (Basella alba L.) \\
\hline Calamansi (Citrofortunella microcarpa) \\
\hline Celery (Apium graveolens) \\
\hline Gabi (Colocasia esculenta) \\
\hline Kamaria (Artemisia vulgaris Linn.) \\
\hline Kangkong (Ipomoea aquatica) \\
\hline Kintsay (Apium graveolens Linn.) \\
\hline Leek (Allium ampeloprasum var. porrum) \\
\hline Lemon grass (Cymbopogon citratus) \\
\hline Mustasa (Sinapsis integrifolia) \\
\hline Niyog-niyogan (Quisqualis indica L.) \\
\hline Okra (Abelmoschus esculentus) \\
\hline Oregano (Coleus aromaticus Benth.) \\
\hline Pakô (Athyrium esculentum) \\
\hline Pandan (Pandanus amaryllifolius) \\
\hline Papaya (Carica papaya) \\
\hline Parsley (Petroselinum crispum) \\
\hline Pechay (Brassica rapa) \\
\hline Saluyot (Corchurus olitorious) \\
\hline Sampa-sampalukan (Phyllantus nimuri) \\
\hline Sili (Capsicum frutescens) \\
\hline Spinach (Spinacea oleracea) \\
\hline Stevia (Stevia rebaudiana L) \\
\hline Sweet potato (Ipomoea batatas) \\
\hline Tsaang-gubat (Carmona retusa) \\
\hline
\end{tabular}

Findings of the study showed that the isolation of LAB from 25 plant leaves samples yielded 650 isolates that exhibited clearing on MRS agar with $\mathrm{CaCO}_{3}$ after repeated serial dilutions and pour plating. Calcium carbonate was used as an indicator for acid-producing strains since it gets degraded with interaction to acids forming a clear zone around the colony. However, only 362 isolates were identified as LAB based on being catalase negative and Gram-positive. From these, 65 representative isolates were randomly selected in which 20 were rod-shaped, ten were cocci, and 35 were coccoid or ovoid.

Five LAB isolates (Lb6, Lb17, Lb21, Lb24 and Lb29) from ripe cape gooseberry fruit and two LAB isolates from ripe guava fruit were also included in this study.

\subsection{Characterization of probiotic properties}

LAB produce antimicrobial compounds, such as bacteriocins, organic acids, hydrogen peroxide and diacetyl, that inhibit the growth of pathogenic and spoilage bacteria. Some LAB also possesses antibiotic resistance to certain levels of antibiotics. There are likewise possibilities on the transfer of antibiotic resistance genes from beneficial microorganisms to pathogens through bacterial conjugation or transposition 
of insertion elements when the antibiotic resistance markers are plasmid-borne.

\subsubsection{Antimicrobial activity assay}

Figure 1 shows zones of inhibition indicating

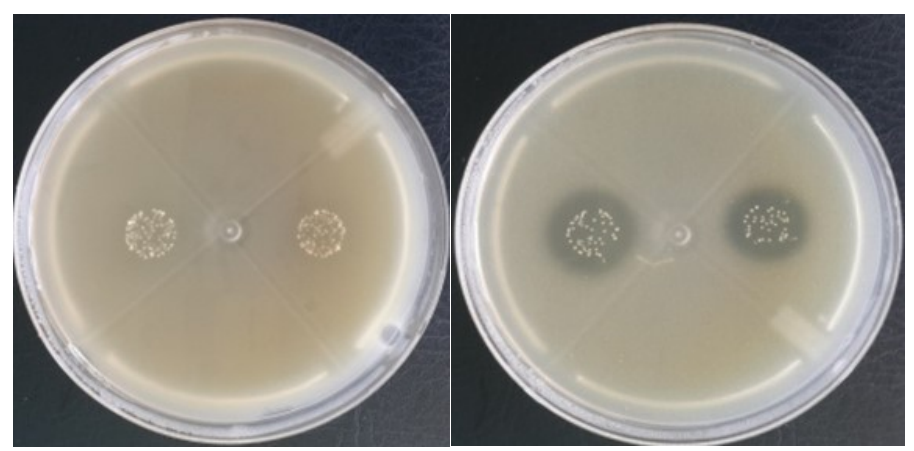

Figure 1. Antimicrobial assay by dual overlay agar method showing zones of inhibition. No zones of inhibition (left) indicate no antimicrobial activity while presence of zones of inhibition (right) indicate antimicrobial activity of the test LAB against the lawn of pathogen added in the basal medium.

antimicrobial activity against the lawn of pathogen. Figure 2 meanwhile shows that the highest antimicrobial activity was exhibited by cape gooseberry or lobolobohan ripened fruit isolates, followed by the stevia leaf isolates. The isolate from guava fruit exhibited resistance against guava leaf extract (Saguibo et al., 2012). In general, Lb17 (identified as Streptococcus luteciae in the latter part of the study) from ripe gooseberry fruit exhibited the highest antimicrobial activities against Staphylococcus aureus, Escherichia coli O157: H7 and Bacillus cereus.

As depicted in Figure 2, the different LAB isolates demonstrated varying degrees of antimicrobial activity based on the diameter of zones of inhibition against the growth of the different pathogenic microorganisms. LAB isolate Lb17 showed the highest antimicrobial activities against Gram-positive $S$. aureus $\left(34.61 \mathrm{~mm}^{2} /\right.$ cell), $B$. cereus $\left(27.49 \mathrm{~mm}^{2} /\right.$ cell) and L. innocua $\left(9.42 \mathrm{~mm}^{2} /\right.$ cell). On the other hand, LAB isolates Lb21 showed best antimicrobial activities against Gram-negative E. coli (15.56 $\mathrm{mm}^{2} /$ cell), E. coli O157: $\mathrm{H} 7\left(16.33 \mathrm{~mm}^{2} /\right.$ cell, although Lb17 had $16.75 \mathrm{~mm}^{2} /$ cell zone of inhibition) and $S$. enterica serovar Typhimurium $\left(11.34 \mathrm{~mm}^{2} /\right.$ cell $)$. This result suggests the preservative effect of Lb17 and Lb21 when used in food fermentation because of their ability to inhibit food-borne pathogens.

\subsubsection{Antibiotic susceptibility test}

The minimum inhibitory concentration (MIC) is defined as the lowest concentration (in $\mathrm{mg} / \mathrm{L}$ ) of the antimicrobial agent that prevents visible growth of a microorganism under defined conditions. According to EFSA (2015), strains can be categorised as susceptible to antimicrobials, when it is inhibited at a concentration of a specific antimicrobial equal or lower than the established cut-off value $(\mathrm{S} \leq \mathrm{x} \mathrm{mg} / \mathrm{L})$ or resistant to antimicrobials, when it is not inhibited at a concentration of a specific antimicrobial higher than the established cut -off value $(\mathrm{R}>\mathrm{x} \mathrm{mg} / \mathrm{L})$. The established cut-off for ampicillin and streptomycin in Lactobacillus strains is varied ranging from $1-4 \mathrm{mg} / \mathrm{L}$ and $16-64 \mathrm{mg} / \mathrm{L}$, respectively. For other $\mathrm{LAB}$ genera, a similar range is tabulated for ampicillin, but a higher range of 32-128 $\mathrm{mg} / \mathrm{L}$ for streptomycin.

Figure $3 \mathrm{a}$ presents the MIC of lactic acid bacteria isolates against ampicillin. Lactobacillus fermentum F36 had MIC of $2 \mathrm{ug} / \mathrm{mL}$ ampicillin which conforms to the established cut-off value. Thus, F36 and all the other lactic acid bacteria tested are considered susceptible because they are inhibited at equal or lower concentrations than the established cut-off value.

Figure $3 \mathrm{~b}$ presents the MIC of lactic acid bacteria isolates against streptomycin. Enterococcus hirae (H and S63) from stevia, Pediococcus pentosaceous (Par5 and NN39) and the unidentified SP5 and SP6 had the MIC of $128 \mu \mathrm{g} / \mathrm{mL}$ streptomycin. This value is still considered susceptible for Enterococcus but resistance is observed with Pediococcus (Par5 and NN39). High susceptibility is observed for Streptococcus luteciae Lb17 because they were inhibited at lower concentration $(32 \mu \mathrm{g} / \mathrm{mL})$ than the established cut-off value $(64 \mu \mathrm{g} / \mathrm{mL})$. Also, for Enterococcus hirae A which were inhibited at lower concentration $(32 \mu \mathrm{g} / \mathrm{mL})$ than the established cut-off value $(128 \mu \mathrm{g} / \mathrm{mL})$.

Higher concentrations were set for ampicillin than for streptomycin. LAB is Gram-positive and possess a cell wall that is more susceptible to antibiotics. This is due to a virtually none lipopolysaccharide (LPS) content, low lipid and lipoprotein content, and absence of outer membrane and periplasmic space.

Ampicillin, which is almost similar to amoxicillin, belongs to the penicillin group of beta-lactam antibiotics and is part of the aminopenicillin family. It has an amino group, present on both ampicillin and amoxicillin, that helps these antibiotics pass through the pores of the outer membrane of Gram-negative bacteria, such as E. coli, Proteus mirabilis, Salmonella enterica, and Shigella (Keeton and Gould, 1993).

Ampicillin acts as an irreversible inhibitor of the enzyme transpeptidase, which is needed by bacteria to make the cell wall. Its bacteriolytic action results from inhibition of the third and final stage of bacterial cell wall synthesis in binary fission (Gallagher, 2011). 


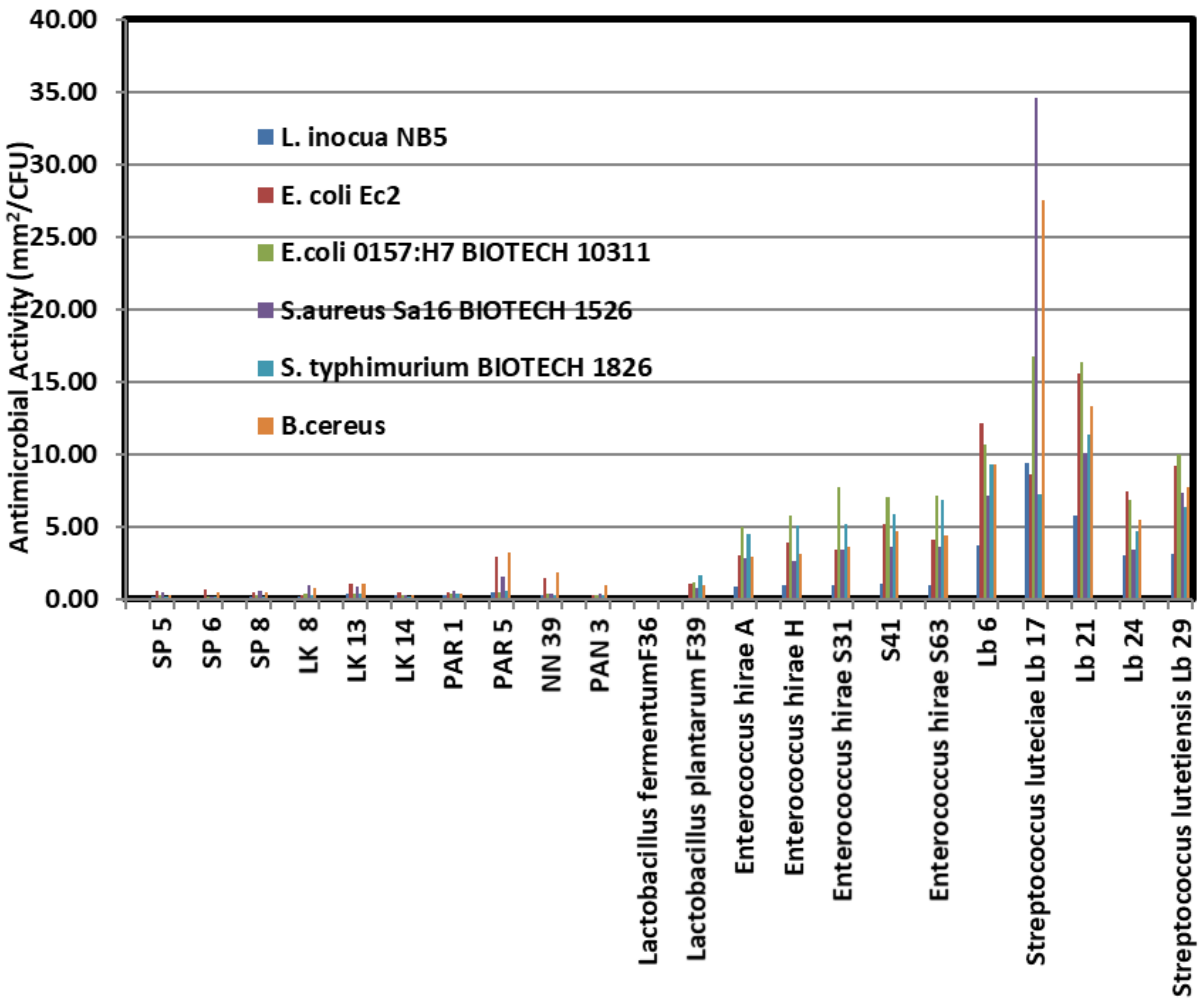

Figure 2. Antimicrobial activity of lactic acid bacteria isolates.

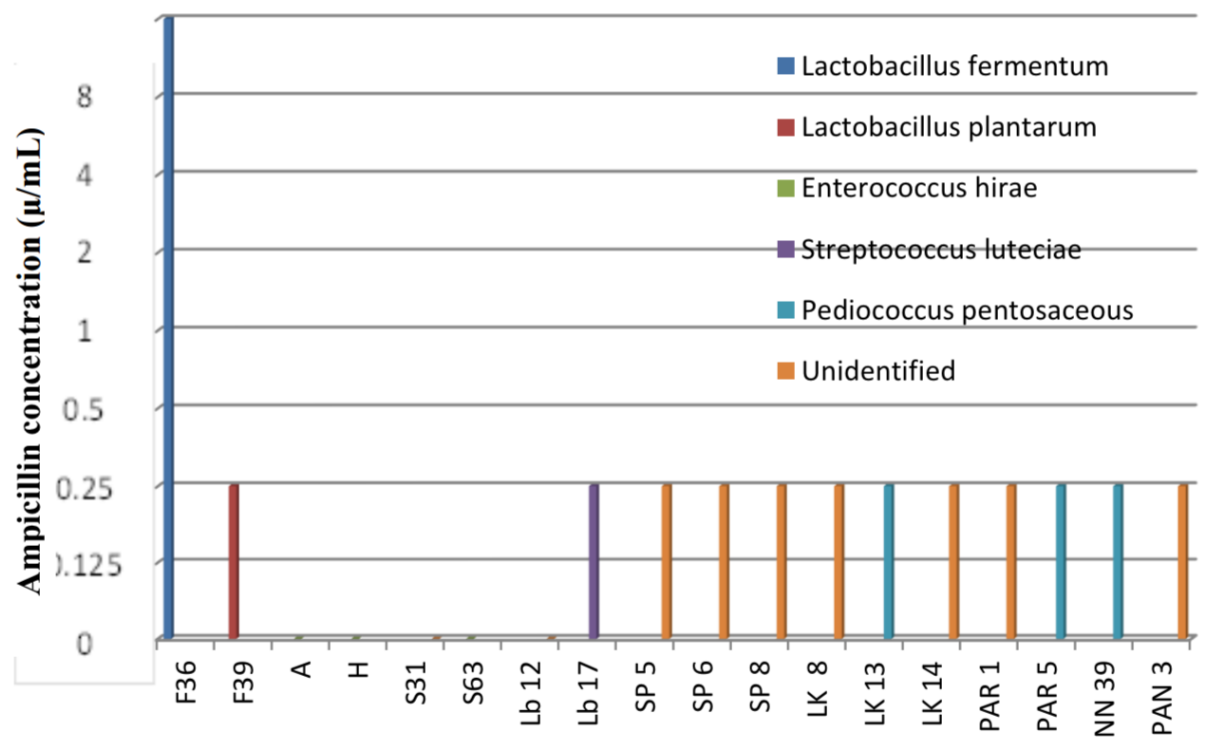

Figure 3a. Susceptibility of lactic acid bacteria isolates against ampicillin.

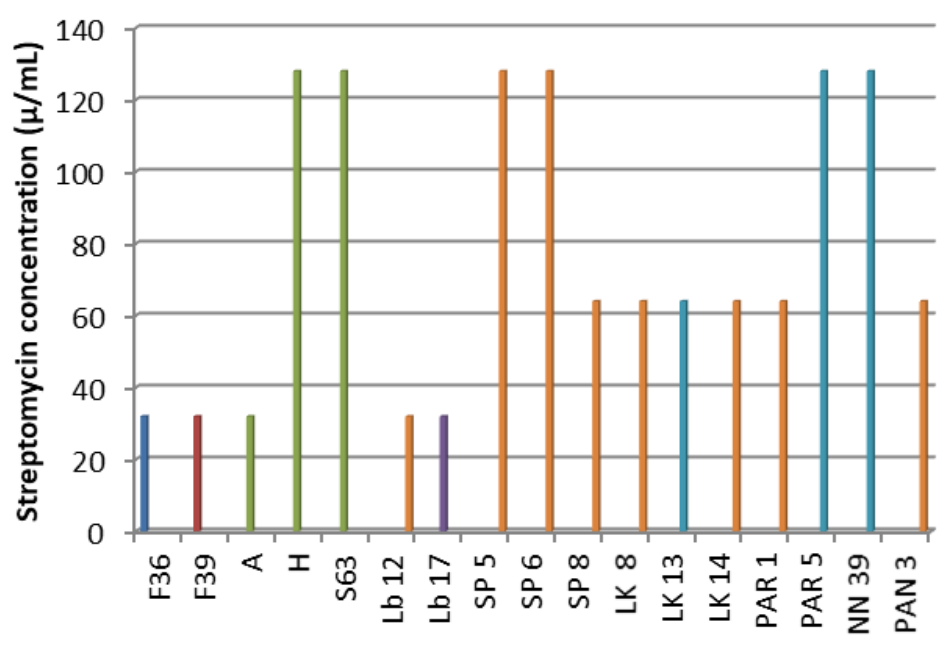

- Lactobacillus fermentum

- Lactobacillus plantarum

Enterococcus hirae

Streptococcus Iuteciae

- Pediococcus pentosaceous

Unidentified

Figure 3b. Susceptibility of lactic acid bacteria isolates against streptomycin. 
On the other hand, streptomycin is an antibiotic drug of the class aminoglycosides, derived from the actinobacterium Streptomyces griseus. It stops bacterial growth by damaging cell membranes and inhibiting protein synthesis. Specifically, it binds to the 16S rRNA of the bacterial ribosome, interfering with the binding of formyl-methionyl-tRNA to the $30 \mathrm{~S}$ subunit. This prevents the initiation of protein synthesis (Gallagher, 2011).

The antibiotic resistance of some LAB may be advantageous to patients who are undergoing antibiotic therapy while taking probiotics to boost their immune response. However, there is speculation that antibiotic resistance genes that are plasmid-borne could be transferred from beneficial microorganisms to pathogens through bacterial conjugation or transposition of insertion elements. It is therefore relevant to further investigate the extent of antimicrobial activity and antibiotic susceptibility of $\mathrm{LAB}$ strains isolated from traditional fermented food and local herbage or plants. It is also recommended to conduct transconjugation experiments. Relevant studies on this subject include the susceptibility of Lactobacillus species to cell wall synthesis inhibitors such as ampicillin and penicillin which have been reported by Danielsen and Wind (2003). Coppola et al. (2005), Sharma et al. (2018) and Rozos et al. (2018) also observed resistance against various antibiotics by some lactobacilli isolated from cheese and commercial probiotic products. In a study by Huys et al. (2002), the resistance patterns were significantly affected by the medium such as MRS agar.

\subsubsection{Acid and bile tolerance}

Probiotics possess intestinal absorption ability and tolerance for gastric acid (a thin, almost colorless liquid secreted by the glands in the lining of the stomach that is strongly acidic with $\mathrm{pH}$ varying from 1 to 3 ), enzymes and bile (yellowish brown fluid, comprising salts (basic), pigments, lecithin and cholesterol, which aids in the process of digestion). These facilitate the probiotics' survival up to the gut system to promote significant health benefits to the host. The findings of this study show that all LAB isolates decreased in number but were able to survive in artificial gastric juice $(\mathrm{pH} 2)$ and then revived upon exposure to simulated intestinal fluid $(\mathrm{pH}$ 8 ), with $50-80 \%$ survival.

\subsubsection{Titratable acidity and diacetyl test}

Titratable acidity is defined as the amount of titrant needed to react stoichiometrically with LAB in milk (Wehr and Frank, 2004). Titration measures all of the acids in milk including its apparent acidity. Any increase in acidity due to the formation of lactic acid, known as the major organic acid produced during the process, is also identified through titration. According to Lindgren and Dobrogosz (1990), the levels and types of organic acids produced during the fermentation process depending on the LAB species or strains, culture composition and growth conditions. The reduction of $\mathrm{pH}$ is relative to the antimicrobial effect of organic acids, as well as the undissociated form of the molecules.

On the other hand, diacetyl or 2,3-butanedione is the most important flavor compound in lactic cultures, cultured buttermilk, butter and others (Jay, 2000). Its presence may be detected although little change in total acidity or $\mathrm{pH}$ has been noted.

Results of this study show that all LAB isolates tested had titratable acidity of about $0.3-0.5 \%$ and very distinct diacetyl formation. Figure 4 shows the top 5 lactic acid producer, F39 and LK8 being the highest.

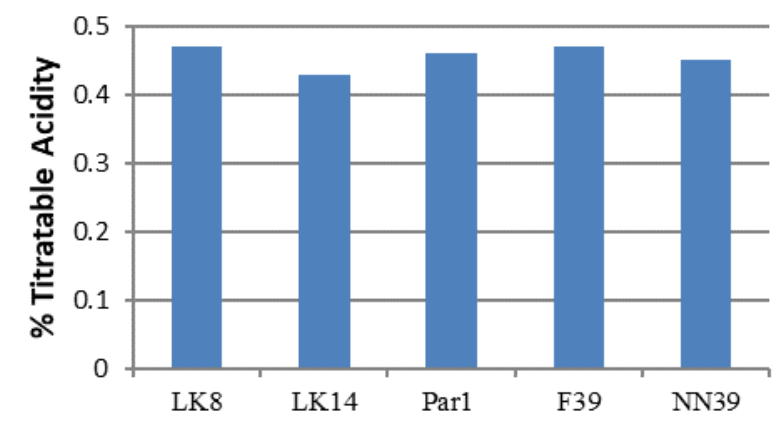

Figure 4. Titratable acidity of the top 5 LAB (two replications).

$\mathrm{LAB}$, the most widely used as starter culture in food fermentation (Hwanhlem et al., 2011), owe their desirable properties to their ability to produce organic acids (predominantly lactic acid and other antimicrobial metabolites such as ethanol, hydrogen peroxide, diacetyl (an aroma compound) and bacteriocins (Diop et al., 2010). Desirable properties of LAB could be improved by the use of mixed starter culture, depending on the food application.

\subsubsection{Genetic screening of plantaricin gene}

LAB produce antimicrobial peptides, called bacteriocins, which are potent at pico- to nanomolar concentrations. These bacteriocins are divided into two main classes: the class I lantibiotics that contain posttranslationally modified lanthionine residues and the class II non-lantibiotics that do not contain extensive modifications. The class II bacteriocins may be further divided into four subclasses: the class IIa pediocin-like bacteriocins that have similar amino acid sequences, the class IIb two-peptide bacteriocins that consist of two different peptides, the class IIc cyclic bacteriocins and the class IId noncyclic one peptide non-pediocin-like 
bacteriocins (Ekblad, 2016).

Plantaricin EF is a two-peptide bacteriocin that depends on the complementary action of two different peptides, PlnE and PlnF, to function (Ekblad et al., 2016). On the other hand, plnJ is part of the threedimensional structure of the two-peptide bacteriocin pln JK (Rogne, 2009).

Together with the other $L b$. plantarum isolates, Lactobacillus plantarum F39 and Lb. fermentum F36 amplified a 450 bp product with pln EF primers indicative of the presence of the structural EF gene. $L b$. fermentum F36 was PCR positive for the pln J gene (data not shown).

For verification of the genes, the EF and $\mathrm{J}$ gene amplicons were submitted to $1^{\text {st }}$ BASE Pte Ltd., Singapore for DNA sequencing. Determination of DNA homologies using BLAST showed that the F39 plnEF and plnJ amplicons had 100\% and 99\% identification with the plantaricin gene locus of Lb. plantarum subsp. plantarum strain YM-4-3. Likewise, F36 plnEF and plnJ amplicons had $100 \%$ homology with the plantaricin gene locus of $L b$. plantarum subsp. plantarum strain YM-4-3. Alignment of the F39 and F36 translated sequences with the plantaricin locus of $L b$. plantarum subsp. plantarum strain YM-4-3 indicated identical peptide sequences of the partial plnE gene and plnF genes of the three strains (data not shown.). With the plnJ peptide sequence, F39 differed with YM-4-3 by a single amino acid, having a threonine (T) instead of an isoleucin (I) (data not shown). On the other hand, the F36 plnJ peptide sequence was found to be identical with that of YM-4-3 (data not shown).

\subsubsection{Identification and fingerprinting}

Table 3 summarizes the sources, identity and fingerprint of selected $\mathrm{LAB}$ isolated from plants. The repetitive sequence-based PCR of $L b$. plantarum and $L b$. fermentum strains generated DNA markers for identification at the species level and for strain differentiation. Distinct strain-specific markers for $L b$. fermentum F36 was obtained in its repetitive Extragenic Palindromic (REP) sequences and BOX profiles. However, Lb. plantarum F39 did not show specific marker in its REP and BOX profiles. Lb. plantarum strains showed specific markers in ERIC PCR and BOX A1R sequences which could serve as markers (Perez et al., 2013; Perez et al., 2014).

LAB isolated from plants is very diverse. However, most of these are soil residents that are probably from animal wastes. Probiotic LAB is normal microflora of the gut of humans and other animals especially birds and insects, which also feed on the fruits of the plants. Although enterococci are implicated in nosocomial infections, recent findings show their probiotic potential particularly in the treatment of diarrhea (Franz et al., 2011). In this study, Streptococcus hirae and Streptococcus lutetiensis were isolated from stevia leaves and ripe cape gooseberry fruit. Further study is recommended to determine their safety and probiotic potentials.

\section{Discussion}

\subsection{Isolation of $L A B$ from non-dairy sources}

LAB comprise groups of Gram-positive bacteria with low-GC content, acid-tolerant, generally nonsporulating, non-respiring, occasionally non-motile rod or cocci, either in pairs or in chains that are associated by their common metabolic and physiological

Table 3. Summary of sources, identity and fingerprint of lactic acid bacteria.

\begin{tabular}{|c|c|c|c|}
\hline Lactic Acid Bacteria & Source & Identity by $16 \mathrm{~S}$ rRNA (\% Homology) & Fingerprint \\
\hline F36 & Guava fruit (Psidium guajava L) & Lactobacillus fermentum (100\%) & Yes \\
\hline F39 & Guava fruit (Psidium guajava $L$ ) & Lactobacillus plantarum (100\%) & Yes \\
\hline PAR 5 & Parsley (Petroselinum crispum) & Pediococcus pentosaceous ATCC 25745 (99\%) & No \\
\hline LK 13 & Leek (Allium ampeloprasum var. porrum) & Pediococcus pentosaceous ATCC 25745 (96\%) & No \\
\hline NN39 & Niyog-niyogan (Quisqualis indica L.) & Pediococcus pentosaceous ATCC 25745 (99\%) & No \\
\hline A & Stevia (Stevia rebaudiana L) & Enterococcus hirae $(98 \%)$ & No \\
\hline $\mathrm{H}$ & Stevia (Stevia rebaudiana L) & Enterococcus hirae $(98 \%)$ & No \\
\hline S31 & Stevia (Stevia rebaudiana L) & Enterococcus hirae $(96 \%)$ & No \\
\hline S41 & Stevia (Stevia rebaudiana L) & Not yet identified & No \\
\hline S63 & Stevia (Stevia rebaudiana $L$ ) & Enterococcus hirae $(88 \%)$ & No \\
\hline Lb6 & Cape goose-berry fruit (Physalis peruviana) & Not yet identified & No \\
\hline Lb17 & Cape goose-berry fruit(Physalis peruviana) & Streptococcus luteciae (98\%) & No \\
\hline $\mathrm{Lb} 21$ & Cape gooseberry fruit(Physalis peruviana) & Not yet identified & No \\
\hline $\mathrm{Lb} 24$ & Cape goose-berry fruit(Physalis peruviana) & Not yet identified & No \\
\hline $\mathrm{Lb} 29$ & Cape goose-berry fruit (Physalis peruviana) & Streptococcus lutetiensis (96\%) & No \\
\hline
\end{tabular}


characteristics. Some LAB is commonly known as probiotics due to their properties as living microorganisms which upon ingestion by the host in certain numbers exert health effects beyond inherent basic nutrition. They are considered generally regarded as safe or GRAS microorganisms. LAB is presently classified to the following five core genera: Lactobacillus, Leuconostoc, Pediococcus, Lactococcus and Streptococcus (Hutkins, 2006).

The lactic acid group of bacteria occur on plants with some degree of constancy, but not of consistency, and seldom at high levels of the population. Their role on the surfaces of plants is unknown, and apparently passive, for no functional, concrete role in an intimate bacterium to plant relationship has been detected (Mundt, 1970). Their recent applications on fiber fermentation such as in silage, organic decomposition such as in manure and sewage treatment and as plant growth promoter when used for soil humus formation, reflect their ability to produce various important enzymes necessary to digest plant components.

The utilization of $\mathrm{LAB}$ in food preservation, including plant-based food products, has long been practiced since time immemorial. Their occurrence was reported in raw plant food material (Mundt, 1970), from plants and other vegetable matrices (Anacarso et al., 2015) or fermented plant beverage and pickles (Duangitcharoen et al., 2008). It was likewise found not only on leaves but also on fruits and flowers (Endo 2012) of various plants including medicinal herbs (Cakir, 2010) and even in extreme environments of mountains, desert and coastal regions (Kuda et al., 2016). The discovery of new potential strains is important in fermentation and preservation of food (Rhee et al., 2011; Admassie, 2018).

Plants synthesize a vast range of organic compounds that are traditionally classified as primary and secondary metabolites. Based on their biosynthetic origins, plant secondary metabolites can be divided into three major groups: (i) flavonoids and allied phenolic and polyphenolic compounds, (ii) terpenoids and (iii) nitrogen-containing alkaloids and sulphur-containing compounds (Crozier, 2007).

Tannins are naturally occurring plant polyphenols, whose main function are binding and precipitating proteins. Tannins are common in fruits (grapes, persimmon, blueberry, etc.), tea, and chocolate. It can also be found in legume forages (trefoil, etc.), legume trees (Acacia spp., Sesbania spp., etc.), and in grasses (sorghum, corn, etc.). Discussion on Cornell University's website about poisonous plants also states that tannins are "responsible for the astringent taste we experience when we partake wine or unripe fruits, and for the enchanting colors seen in flowers and in autumn leaves" (Cannas, 2018).

Isolation and utilization of $\mathrm{LAB}$ in the fermentation of high tannin-containing plants were already reported by several researchers. Okada (2002) noted that only $L b$. plantarum equipped with DAP-peptidoglycan in cell wall participate in the fermentation of tea leaves because of their ability to survive from tannic acids contained in the leaves. However, LAB equipped with Lyspeptidoglycan in cell wall were unable to survive. Jakesevic (2011) meanwhile conducted a study on probiotics and berry-associated polyphenols, its catabolism, and antioxidative effects. There is also evidence that fermentation with LAB decreased the concentration of polyphenols and significantly changed the polyphenols profile in the fermented buckwheat flours (Wiczkowski et al., 2016). Tannase activity was also observed in Xuan mugua fruits fermented with $L b$. plantarum (Shang et al, 2019). This was also evident in Lactobacillus strains isolated from grape must and wine (Vaquero et al., 2004). Also on Lb. plantarum and $L b$. pentosus in tea extracts (Chaikaew, 2018) and Lb. brevis isolated from fermented foods (Kivanci and Temel, 2018).

\subsection{Antibiotic resistance}

Antibiotic resistance is one of the biggest threats to global health. It occurs naturally, but misuse of antibiotics in humans and animals accelerates the process. A growing number of infections such as pneumonia, tuberculosis, gonorrhoea and salmonellosis, are becoming harder to treat as the antibiotics used for treatment become less effective. This scenario results in longer hospitalization, higher medical costs and increased mortality (WHO, 2018).

Because of the growing concern of antibiotic resistance, substantial pressure to reduce antibiotic use has necessitated the development of antibiotic alternatives. Mathur et al. (2017) reviewed studies in which bacteriocins were found to be effective in combination with other antimicrobials. The authors particularly discussed the combination of lantibiotics with antibiotics against clinical and veterinary pathogens, sanctibiotics and other groups of bacteriocins in combination with antimicrobials against clinical pathogens, and effective bacteriocin-antimicrobial combinations against biofilms. Other combinations studied included effects of antimicrobial combinations involving bacteriocins against food-borne pathogens, combinations of bacteriocins with essential oils, and naturally-derived compounds and preservatives against gram-positive food-borne pathogens. Also discussed 
were bacteriocins in combination with other stressors against Gram-negative food-borne pathogens, bacteriocins in combination with antibiotics against food -borne pathogens, and other strategies such as bacteriocin in combination with phages/endolysins. A bacteriocin active against multi-resistant gram-negative bacteria in nosocomial infections was also reported (Ghodhbane, 2015).

Bacteria, in general, are very adaptable creatures and capable of continuous evolution in order to survive stressors present in their environments such as bacteriophages, antibacterial metals, minerals, and nanoparticles, organic acids, essential oils, and probiotics. The development of antibiotic alternatives necessitates extra caution because of the possibility to develop resistance to these alternatives. There are opportunities to optimize antibiotic alternative effectiveness as well as to minimize the development of resistance mechanisms (Willing et al., 2018). Many investigators have speculated that commensal bacteria including LAB may act as reservoirs of antibiotic resistance genes similar to those found in human pathogens. Genes conferring resistance to tetracycline, erythromycin and vancomycin have been detected and characterized in Lactococcus lactis, Enterococci and in Lactobacillus species isolated from fermented meat and milk products (Mathur and Singh, 2005).

\subsection{Ensuring safety of probiotics}

Since most probiotics are marketed as foodstuff or drugs, thorough consideration of its safety is therefore of utmost importance. Most probiotics used in humans are commonly isolated from dairy food. Increasingly, probiotics from sources other than milk products are being selected for use in people who are lactose intolerant. These sources are non-dairy fermented foods and beverages, non-dairy and non-fermented foods such as fresh fruits and vegetables, feces of breast-fed infants and human breast milk (Sornplang and Piyadeatsoontorn, 2016).

The selection criteria for probiotics can be microbiological, technological and clinical. For microbiological, LAB strains must be accurately identified, nonpathogenic, acid and bile stable, produce important enzymes and genetically stable during storage (Holzapfel et al., 2001, Tannock 2001; Ishibashi and Yamazaki, 2001). Under the technological criterion, selected probiotics can be cultured in industrial scale, viable and able to survive throughout manufacturing and storage. In Japan, a standard was developed by the Fermented Milk and Lactic Acid Bacteria Beverage Association stipulating that a product must contain $\geq 1 \times 10^{7}$ viable bifidobacteria/g or $\mathrm{ml}$ product to be considered as probiotic food with a proposed therapeutic minimum dose of $1 \times 10^{5}$ viable cell/g or $\mathrm{ml}$ product (Stanton, 2001). Microencapsulation or immobilization and incorporation of prebiotics are performed to ensure viability (Charalampopoulos et al., 2002). Generally, the viability of some strains is dependent on their resistance to the conditions for production. Other criteria are the availability of suitable carrier/fermenting substance, acceptable product quality and production of diacetyl compounds responsible for flavor, as well as mild acidity throughout storage. The clinical criterion, on the other hand, states that probiotics must adhere and colonize the human gut and produce antimicrobial substances such as lactic acid, $\mathrm{H}_{2} \mathrm{O}_{2}$, bacteriocins (Dunne et al., 2001). Prior to food incorporation, determination of probiotic properties, as well as comparison to known probiotics for that particular food, are deemed important (Nomura et al., 2006).

\subsection{Health benefits of probiotics}

Claims relating to probiotic properties vary from the prevention of infectious diseases (Rolfe, 2000), curing of irritable bowel syndrome, alleviation of allergies, digestion of lactose and lowering of serum cholesterol levels (Anderson et al., 2001) to the prevention of cancer (Gibson and MacFarlane, 1994). Dicks and Botes (2010) published a comprehensive review on health benefits, safety and mode of action of probiotic LAB in gastrointestinal tract. Similarly, Fijan (2014) published an overview of recent literature on microorganisms with claimed probiotic properties which include Lactobacillus, Bifidobacterium, Saccharomyces, Enterococcus, Streptococcus, Pediococcus, Leuconostoc, Bacillus, Escherichia coli. Probiotics have been found to promote good health for persons with autism (PWA) as well (Adams et al., 2011; Gilbert et al., 2013; Kerns et al., 2017).

In assessing the quality and efficacy of the health benefits of probiotic products, a statistically acceptable clinical trial is recommended in addition to the validation studies conducted in animal models (Tamayo, 2008; Degnan, 2012). Reid et al. (2003) reviewed the numerous potential uses of probiotics in clinical practices. Several clinical trials have already been reported on glycemic control (Ruan et al., 2015; Li et al., 2016) in patients with cirrhosis (Horvath et al., 2016).

However, the use of various probiotics for immunocompromised patients or patients with a leaky gut has also yielded infections, sepsis, fungemia, bacteraemia. Although the vast majority of probiotics that are used today are generally regarded as safe and beneficial for healthy individuals, caution in selecting and monitoring of probiotics for patients is needed and 
complete consideration of risk-benefit ratio before prescribing is recommended (Fijan, 2014).

\subsection{Probiotics and functional beverage}

Due to growing vegetarianism and the large number of individuals who are lactose intolerant or prescribed with cholesterol-restricted diets, the development of nondairy probiotic products, including food matrices based on fruit, vegetables and cereals, has been widely studied (Furtado Martins et al., 2013). Non-dairy probiotic beverages, whether fermented or non-fermented, can also play an important role in probiotic delivery (Ranadheera et al., 2017).

In fact, consumption of lactic acid fermented vegetable juice is now becoming more popular in many countries, including those in Europe, China, Japan and Korea. Generally, fermentation is carried out to enhance taste, aroma, shelf-life, texture, nutritional value and other properties of food. Lactic acid fermented vegetable juices can be produced by fermenting the vegetable the usual way and then processing it by pressing the juice or by first, processing the vegetable to mash or raw juice before fermentation. Fermentation of vegetable juices can be through spontaneous by natural microflora, or addition of starter cultures and fermentation of heattreated or pasteurized materials by starter cultures at a concentration of $10^{5}$ to $10^{7} \mathrm{CFU} / \mathrm{mL}$. For fermentation of juices, the most important LAB belong to genus Lactobacillus, Pediococcus and Bifidobacteria and the yeast, Saccharomyces cerevisiae boulardii (Karovicova and Kohajdova, 2005).

In general, fermentation improves the nutritional value of a particular food by affecting its digestibility and nutrient content through enhancing its nutrient density and increasing the amount and the bioavailability of nutrients (Svanberg and Lorri, 1997). Lactic acid fermentation leads to a decrease in the level of carbohydrates as well as some non-digestible poly- and oligosaccharides (Friend and Shahani, 1984). The latter reduces side effects such as abdominal distension and flatulence (Nout and Motarjemi, 1997). It also increases the utilization of iron from food by the breakaway of inorganic iron from complex substances under the influence of vitamin C (Siegenberg, 1991; Venkatesh, 1998). In addition, acid-fermented vegetables are important sources of vitamins and minerals (Lee, 1987). Vitamin $\mathrm{C}$ is better preserved in lactic acid-fermented vegetable products, compared to those processed by alternative methods (Nout and Motarjemi, 1997). Researchers similarly concluded that fermented vegetable juice combines the benefits of vegetable-based products besides functional roles occurring from the existence of viable probiotics in a proper amount during the shelf life (Profir et al., 2015). Beverages are by far the most active functional food category because of convenience and possibility to meet consumer demands for container contents, size, shape, and appearance, as well as ease of distribution and storage for refrigerated and shelf-stable products. Moreover, they are an excellent delivering means for nutrients and bioactive compounds including vitamins, minerals, antioxidants, $\omega$ -3 fatty acids, plant extracts, fiber, prebiotics, and probiotics (Corbo et al., 2014).

Tamang et al. (2016) meanwhile reviewed the various functional properties of microorganisms in fermented food, such as anti-oxidant activity, peptide production, enzyme production, increase in isoflavones and saponins and production of polyglutamic acid (PGA), degradation of anti-nutritive compounds, and synthesis of nutrient which has direct or indirect contributing effects on health.

\section{Conclusion}

Plants, besides other sources, are also good sources of probiotic LAB. Therefore, plants could have inherent characteristics that are advantageous in product development. The thorough characterization of the probiotic properties of these locally isolated probiotic LAB would dictate their industrial relevance particularly in the development of plant-based nutraceutical or functional foods. Further study is recommended to determine their safety and understand deeply their probiotic potentials. The demand for healthier alternatives and healthier food products remains a challenge for researchers. This underscores the importance of engaging in similar probiotics and $\mathrm{LAB}$ research analysis.

\section{Acknowledgment}

This work was supported and funded by the National Research Council of the Philippines under the Department of Science and Technology (NRCP-DOST), the Department of Agriculture (DA) Biotech, and DABureau of Agricultural Research. Acknowledgement is also given to Mr. Guy Ramirez and Lailanie P. Espiritu for their able assistance.

\section{References}

Adams, J.B., Johansen, L.J. Powell, L.D., Quig, D. and Robin R.A. (2011). Gastrointestinal flora and gastrointestinal status in children with autism comparisons to typical children and correlation with autism severity. BMC Gastroenterology, 11(22), 113. https://doi.org/10.1186/1471-230X-11-22.

Admassie, M. (2018). A review on food fermentation 
and the biotechnology of lactic acid bacteria. World Journal of Food Science and Technology, 2(1), 1924. https://doi.org/10.11648/j.wjfst.20180201.13

Agudo, A. (2005). Measuring intake of fruit and vegetables [electronic sources]. Background paper for the Joint FAO/WHO Workshop on Fruit and Vegetables for Health, 1-3 September 2004. Kobe, Japan: WHO.

Cakir, I. (2010). Antibacterial and antifungal activities of some lactic acid bacteria isolated from naturally fermented herbs. Journal of Food, Agriculture and Environment, 8(2), 223-226.

Cannas, A. (2018). Tannins: fascinating but sometimes dangerous molecules Retrieved from Cornell University website: https:// poisonousplants.ansci.cornell.edu/toxicagents/ tannin.html

Chaikaew, S., Baipong, S., Sone, T., Kanpiengjai, A., Chui-Chai, N., Asano, K. and Khanongnuch, C. (2017). Diversity of lactic acid bacteria from Miang, a traditional fermented tea leaf in northern Thailand and their tannin-tolerant ability in tea extract. Journal of Microbiology, 55(9),720-729. https:// doi.org/10.1007/s12275-017-7195-8

Charalampopoulos, D., Wang, R. Pandiella, S.S. and Webb, C. (2002). Application of Cereals and cereal components in functional foods: a review. International Journal of Food Microbiology, 79 (1/2), 131-141. https://doi.org/10.1016/S0168-1605 (02)00187-3

Coppola, R., Succi, M., Tremonte, P., Reale, A., Salzano, G. and Sorrentino, E. (2005). Antibiotic susceptibility of Lactobacillus rhamnosus strains isolated from Permigiano Reggiano cheese. Lait Dairy Science and Technology, 85, 193-204. https:// doi.org/10.1051/lait:2005007

Corbo, M.R., Bevilacqua, A., Petruzzi, L., Casanova, F.P. and Sinigaglia, M. (2014). Functional Beverages: The Emerging Side of Functional Foods. Commercial Trends, Research and Health Implications. Comprehensive Reviews in Food Science and Food Safety, 13(6), 1192-1206. https:// doi.org/10.1111/1541-4337.12109

Cornell University, Department of Animal Science, College of Agriculture and Life Sciences (Cornell CALS). (2019). Department of Animal Science: Plants poisonous to livestock. Retrieved on May 14, 2019 from Cornell University Website: https:// poisonousplants.ansci.cornell.edu/ toxicagents/ tannin.html.

Crozier, E., Clifford, M. and Jaganath, I. (2007). (eds.) Phenols, Polyphenols and Tannins: An Overview. In Plant Secondary Metabolites: Occurrence, Structure and Role in the Human Diet, p. 1 - 24. USA: Blackwell Publishing https:// doi.org/10.1002/9780470988558.ch1

Danielsen, M. and WiInd, A. (2003). Susceptibility of Lactobacillus spp. to antimicrobial agents. International Journal of Food Microbiology, 82(1), 1 -11. https://doi.org/10.1016/S0168-1605(02)00254-4

Degnan, F.H. (2012). Clinical studies involving probiotics. When FDA's investigational new drug rubric applies-and when it may not. Gut Microbes, 3(6), 485-489. https://doi.org/10.4161/gmic.22158

Dicks, L.M.T. and Botes, M. (2010). Probiotic lactic acid bacteria in the gastrointestinal tract: health benefits, safety and mode of action. Beneficial Microbes, 1(1), 11-29. https://doi.org/10.3920/BM2009.0012

Diop, M.B., Dibois-Dauphin, R., Tine, E., Jaqueline, A.N. and Thonart, P. (2007). Bacteriocin producers from traditional food products. Biotechnology Agronomy Society and Environment, 11(4), 275-281.

Dunne, C., O'Mahony, L., Murphy, L., Thornton, G., Morrissey, D., O'Halloran, S., Feeney, M., Flynn, S., Fitzgerald, G., Daly, C., Kiely, B., O'Sullivan, G.C., Shanahan, F. and Collins, J.K. (2001). In vitro selection criteria for probiotic bacteria of human origin: correlation with in vivo findings. American Journal of Clinical Nutrition, 73(2), 386S-392S. https://doi.org/10.1093/ajcn/73.2.386s

Duangjitcharoen, Y., Kantachote, D., Ongsakul M., Poosaran, N. and Chaiyasut, C. (2008). Selection of probiotic lactic acid bacteria isolated from fermented plant beverages. Pakistan Journal of Biological Sciences, 11(4), 652-655. https:// doi.org/10.3923/pjbs.2008.652.655

EFSA Panel on Additives and Products or Substances used in Animal Feed (FEEDAP). (2015). Draft statement on exposure assessment of food enzymes. Retrieved from EFSA journal website: https:// www.efsa.europa.eu/sites/default/files/ consultation/160216.pdf

Ekblad, B., Kyriakou, P.K., Oppegård, C, Nissen-Meyer, J, Kaznessis, Y.N. and Kristiansen, P.E. (2016). Structure-function analysis of the two-peptide bacteriocin plantaricin EF. Biochemistry, 55(36), 5106-5116.

https://doi.org/10.1021/ acs.biochem.6b00588

Endo, A. (2012). Fructophilic lactic acid bacteria inhabit fructose-rich niches in nature. Microbial Ecology in Health and Disease, 23, 18563 https:// doi.org/10.3402/mehd.v23i0.18563

Farnsworth, N.R. and Soejarto, D.D. (1991). Global importance of medicinal plants. In Akerele, O., Heywood, V. and Synge, H. (eds.) The Conservation of Medicinal Plants, p. 25-51. Cambridge, UK: 
Cambridge University Press. https://doi.org/10.1017/ CBO9780511753312.005

Fernandez, M.F., Borris, A. and Barbes, C. (2003). Probiotic properties of human lactobacilli strain to be used in the gastrointestinal tract. Journal of Applied Microbiology, 94(3), 449-445. https:// doi.org/10.1046/j.1365-2672.2003.01850.x

Fijan, S. (2014). Microorganisms with claimed probiotic properties: an overview of recent literature. International Journal of Environmental Research and Public Health, 11(5), 4745-67. https:// doi.org/10.3390/ijerph110504745

Franz, C., Huch, M., Abriouel, H., Holzapfel, W. and Gálvez, A. (2011). Enterococci as probiotics and their implications in food safety. International Journal of Food Microbiology, 151(2), 125-140. https://doi.org/10.1016/j.ijfoodmicro.2011.08.014

Friend, B.A. and Shahani, K.M. (1984). Nutritional and therapeutic aspects of lactobacilli. Journal of Applied Nutrition, 36(2), 125-153.

Fuller, R. (1989). Probiotics in man and animals. Journal of Applied Bacteriology, 32, 439-442. https:// doi.org/10.1136/gut.32.4.439

Furtado Martins, E. M., MotaRamos, A. Vanzela, E. S. L., Stringheta, P.C., Pinto, C.L.O., Martins, J.M. (2013). Products of vegetable origin: A new alternative for the consumption of probiotic bacteria. Food Research International, 51(2), 764-770. https://doi.org/10.1016/j.foodres.2013.01.047

Gallagher, J.C. and MacDougall, C. (2011). Antibiotics Simplified. $2^{\text {nd }}$ ed., p. 272. USA: Jones and Barlette Learning.

Ghodhbane, H, Elaidi, S, Sabatier, J.M., Achour, S., Benhmida, J. and Regaya, I. (2015). Bacteriocins active against multi-resistant gram negative bacteria implicated in nosocomial infections. Infection Disorders Drug Targets, 15(1), 2-12. https:// doi.org/10.2174/1871526514666140522113337

Gilbert, J.A., Krajmalnik-Brown, R., Porazinska, D.L., Weiss, S.J. and Knight, R. (2013). Toward effective probiotics for autism and other neurodevelopmental disorders. Cell, 155(7), 14461448. https://doi.org/10.1016/j.cell.2013.11.035

Holzapfel, W.H., Haberer, P., Geisen, R., Bjorkroth, J. and Schillinger, U. (2001). Taxonomy and important features of probiotic microorganisms in food and nutrition. American Journal of Clinical Nutrition, 73 (2), 365S-373S. https://doi.org/10.1093/ $\mathrm{ajcn} / 73.2 .365 \mathrm{~s}$

Horvath, A., Leber B., Schmerboeck, B., Tawdrous, M, Zettel, G., Hartl, A., Madl, T., Stryeck, S., Fuchs, D., Lemesch, S., Douschan, P., Krones, E., Spindelboeck, W., Durchschein, F., Rainer,
F., Zollner, G., Stauber, R.E., Fickert, P., Stiegler, P. and Stadlbauer, V. (2016). Randomized clinical trial: the effect of a multispecies probiotic vs. placebo on innate immune function, bacterial translocation and gut permeability in patients with cirrhosis. Alimentary Pharmacology and Therapeutics, 44(9), 926-935. https://doi.org/10.1111/apt.13788

Hutkins, W. (2006). Starter cultures. In Hutkins, R.W. (ed.) Microbiology and Technology of Fermented Foods. $1^{\text {st }}$ ed., p. 67-106. USA: Blackwell Publishing. doi.org/10.1002/9780470277515.ch3

Huys, G., D'Haene, K. and Swings, J. (2002). Influence of the culture medium on antibiotic susceptibility testing of food-associated lactic acid bacteria with the agar overlay disc diffusion method. Letters in Applied Microbiology, 34(6), 402-406. https:// doi.org/10.1046/j.1472-765X.2002.01109.x

Hwanhlem, N., Buradaleng, S., Wattanachant, S., Benjakul, S., Tani, A. and Maneerat, S. (2011). Isolation and screening of lactic acid bacteria from Thai traditional fermented fish (Plasom) and production of plasom from selected strains. Food Control, 22(3-4), 401-407. https://doi.org/10.1016/ j.foodcont.2010.09.010

Anacarso, I., Bassoli, L., Sabia, C., Iseppi, R. and Condò, C. (2015). Isolation and identification of lactic acid bacteria from plants and other vegetable matrices and microbial recombination with Enterococcus spp. American Research Thoughts, 1 (7), 1503-1515.

Ishibashi, N. and Yamazaki S. (2001). Probiotics and Safety. American Journal of Clinical Nutrition, 73 (2), 465S-470S. https://doi.org/10.1093/ ajcn/73.2.465s

Jakesevic, M. (2011). Probiotics and berry-associated polyphenols: catabolism and antioxidative effects. Sweden: Lund University, PhD Thesis.

Jay, J.M. (2000). Modern Food Microbiology. Gaithersburg, Maryland, USA: Aspen Publishers, Inc. https://doi.org/10.1007/978-1-4615-4427-2

Joseph, B. and Priya, R.M. (2011). Phytochemical and biopharmaceutical aspects of Psidium guajava (L.) essential oil: a review. Research Journal of Medicinal Plants, 5(4), 432-442. https:// doi.org/10.3923/rjmp.2011.432.442

Kandler, O. (1984). Current taxonomy of Lactobacilli. Industrial Microbiology, 25, 9-123.

Karovicova, J. and Kohajdova, Z. (2005). Lactic acidfermented vegetable juices-palatable and wholesome foods. Chemical Papers, 59(2), 143-148.

Keeton, W.T. and Gould, J.L. (1993). Biological Science. $5^{\text {th }}$ ed. Vol. 2. New York and London: W.W. Norton 
and Company. 1187p.

Kerns, C.M., Renno, P., Storch, E.A., Kendall, P.C. and Wood, J.J. eds. (2017). Anxiety in Children and Adolescents with Autism Spectrum Disorders. Evidence-based Assessment and Treatment. Academic Press. 274pp.

Kivanci, M. and Temel, O. (2018). Tannase activity by Lactobacillus brevis strains isolated from fermented food. Romanian Biotechnological Letters [Accepted].

Kuda, T., Kataoka, M., Nemoto, M., Kawahara, M., Takahashi, H. and Kimura, B. (2015). Isolation of lactic acid bacteria from plants of the coastal Satoumi regions for use as starter cultures in fermented milk and soymilk production. LWT - Food Science and Technology, 68, 202-207. https:// doi.org/10.1016/j.lwt.2015.12.023

Kuete, V. (eds). (2017). Medicinal Spices and Vegetables from Africa, Therapeutic Potential against Metabolic, Inflammatory, Infectious and Systemic Diseases. Academic Press, 694 pp.

Li, F., Fu, L., Zhang, W., Su, X., Wu, J., Sun, J., Ye, L. and Ma, J. (2016). Blood glucose fluctuations in type 2 diabetes patients treated with multiple daily injections. Hindawi Publishing Corporation. Journal of Diabetes Research, 2016, 8. https:// doi.org/10.1155/2016/1028945

Lindgren, S.E. and Dobrogosz, W.J. (1990). Antagonistic activities od lactic acid bacteria in food and feed fermentations. FEMS Microbiology, 70, 7520-7529.

Gopal, M.N., Tejaswini, J., Mantry, S. and Anil Kumar, S. (2014). Review article: International standards for medicinal plants. International Journal of Innovative Pharmaceutical Science and Research, 2 (10), 2498-2532, ISSN (online) 2347-2154.

Mathur, H., Field, D., Rea, M.C., Cotter, P.D., Hill, C. and Ross, R.P. (2017). Bacteriocin-Antimicrobial Synergy: A Medical and Food Perspective. Frontiers in Microbiology, 29(8), 1205. doi: 10.3389/ fmicb.2017. 01205. eCollection 2017. https:// doi.org/10.3389/fmicb.2017.01205

Mathur, S. and Singh, R. (2005). Antibiotic resistance in food lactic acid bacteria-a review. International Journal of Food Microbiology, 105(3), 281-95. https://doi.org/10.1016/j.ijfoodmicro.2005.03.008

Muhialdin, B.J., Hassan, Z., Imdakim, M.M.A. Kahar, F.K.S.A. and Aween, M.M. (2012). Malaysian isolates of lactic acid bacteria with antibacterial activity against Gram- positive and Gram-negative pathogenic bacteria. Journal of Food Research, 1(1), 110-116. https://doi.org/10.5539/jfr.v1n1p110

Mundt, J.O. (1970). Lactic acid bacteria associated with raw plant food material. Journal of Food Protection, 33, 550-553. https://doi.org/10.4315/0022-274733.12 .550

Nomura, M., Kobayashi, M. Narita, T., Kimoto-Nira, H. and Okamoto, T. (2006). Phenotypic and molecular characterization of Lactococcus lactis from milk and plants. Journal of Applied Microbiology, 101(2), 396 -405 .

2672.2006.02949.x

https://doi.org/10.1111/j.1365-

Nout, M.J.R. and Motarjemi, Y. (1997). Assessment of fermentation as a household technology for improving food safety: a joint $\mathrm{FAO} / \mathrm{WHO}$ workshop. Food Control, 8(5-6), 221-226. https:// doi.org/10.1016/S0956-7135(97)00021-2

Okada, S. (2002). The world of plant origin lactic acid bacteria. Japanese Journal of Lactic Acid Bacteria, 13(1), 23-36. https://doi.org/10.4109/jslab1997.13.23

Perez, M.T.M., Saguibo, J.D. Jimeno, B.T., Calapardo, M.R., Mercado, M.A. and Elegado, F.B. (2013). Repetitive sequenced-based PCR and identification of DNA markers in selected lactic acid bacteria strains. Proceedings of the $35^{\text {th }}$ National Academy of Science and Technology (NAST) Annual Scientific meeting, July 11, 2013. Manila, Phillipines: NAST

Perez, M.T.M., Saguibo, J.D., Calapardo, M.R. and Elegado, F.B. (2014). DNA Fingerprinting and Identification of Random amplified Polymorphic DNA markers in Potential Probiotic [Lactobacillus plantarum] Strains. Proceedings of the $43^{\text {rd }}$ Philippine Society for Microbiology (PSM) Annual Convention. May 15-16, 2014. Cebu City, Philippines: Philippine Society for Microbiology

Profir, A.G., Neagu, C.V. and Vizireanu, C. (2015). Impact of nutrients on the probiotic survival and sensory properties of vegetable juice. Romanian Biotechnological Letters, 20(6), 11041-11048.

Ranadheera, C.S., Vidanarachchi, J.K., Rocha, R.S. Cruz, A.G. and Ajlouni, S. (2017). Probiotic delivery through fermentation: Dairy vs. non-dairy beverages. Fermentation, 3(4), 67. https://doi.org/10.3390/ fermentation 3040067

Reid, G., Jass, J., Sebulsky, M.T. and McCormick, J.K. (2003). Potential uses of probiotics in clinical practice. Clinical Microbiology Reviews, 16(4), 658672. https://doi.org/10.1128/CMR.16.4.658672.2003

Rhee, S.J., Lee, J.E. and Lee, C.H. (2011). Importance of lactic acid bacteria in Asian fermented foods. Microbial Cell Factories, 10 (Suppl.) 1, S5. https:// doi.org/10.1186/1475-2859-10-S1-S5

Rogne, P., Hangen, C., Fimland, G., Nissen-Meyer, J.and Kristiansen, P.E. (2009). Three-dimensional structure of the two-peptide bacteriocin plantaricin 
JK. Peptides, 30(9), 1613-1621. https:// doi.org/10.1016/j.peptides.2009.06.010

Rolfe, R.D. (2000). The role of probiotic cultures in the control of gastrointestinal health. The Journal of Nutrition, 130(2), 396S-402S. https:// doi.org/10.1093/jn/130.2.396S

Rozos, G,, Voidarou, C., Stavropoulou, E., Skoufos, I., Tzora, A., Alexopoulos, A. and Bezirtzoglou, E. (2018). Biodiversity and microbial resistance of lactobacilli isolated from the traditional Greek cheese kopanisti. Frontiers in Microbiology, 9, 517. https://doi.org/10.3389/fmicb.2018.00517

Ruan, Y., Sun, J., He, J., Chen, F., Chen, R. and Chen, H. (2015). Effect of probiotics on glycemic control: A systematic review and meta-analysis of randomized, controlled trials. PLoS ONE, 10(7), e0132121. https://doi.org/10.1371/journal.pone.0132121

Saguibo J.D., Jimeno, B.T., Calapardo, M.R., Perez, M.T.M., Ramirez, G.A. and Elegado, F.B. (2012). Isolation and screening of resistant lactic acid bacteria against guava leaf extract and the hypoglycemic effect of its fermentation on mice. Journal of Engineering Technology and Education, College of Engineering, National Kaohsiung University of Applied Science, Taiwan, 9(9), 59-65.

Saguibo, J.D. and Elegado, F.B. (2012). Resistance profile of probiotic lactic acid bacteria against inhibitory effects of selected plant extracts. Philippine Agricultural Scientist, 95(1), 22-32.

Shang,Y., Cao, H., Ma, Y., Zhang, C., Ma, F., Wang, C., Ni, X., Lee, W. and Wei, Z. (2019). Effect of lactic acid bacteria fermentation on tannins removal in Xuan mugua fruits. Food Chemistry, 274, 118122. https://doi.org/10.1016/j.foodchem.2018.08.120

Sharma, P., Anand, S., Tomar, S.K. and Goswami, P. (2018). Antibiotic susceptibility of Lactobacillus sp. Isolated from commercial probiotic products by ETest strip method. International Journal of Current Microbiology and Applied Sciences, 7(4), 34993517. https://doi.org/10.20546/ijcmas.2018.704.396

Siegenberg, D., Baynes, R.D., Bothwell, T.H., MacFarlane, B.J., Lamparelli, R.D., Car, N.G., MacPhail, P., Schmidt, U., Tal, A. and Mayet, F. (1991). Ascorbic acid prevents the dose-dependent inhibitory effects of polyphenols and phytates on non -heme iron absorption. American Journal in Clinical Nutrition, 53(2), 537-541. https://doi.org/10.1093/ ajcn/53.2.537

Sornplang, P. and Piyadeatsoobtorn, S. (2016). Probiotic isolates from unconventional sources: a review. Journal of Animal Science and Technology, 58, 26. https://doi.org/10.1186/s40781-016-0108-2

Stanton, C., Gardiner, G., Meehan, H., Collins,
K., Fitzgerald, G., Lynch, P.B., and Ross, R.P. (2001). Market potential for probiotics. American Journal of Clinical Nutrition, 73(2), 476S-483S. https://doi.org/10.1093/ajcn/73.2.476s

Tamang, J.P., Shin, D., Jung, S. and Chae, S. (2016). Review: Functional Properties of Microorganisms in Fermented Foods. Frontiers in Microbiology, 7, 578. https://doi.org/10.3389/fmicb.2016.00578

Tamayo, C. (2008). Clinical research on probiotics:The interface between Science and Regulation. Clinical Infectious Diseases, 46, S101-103. https:// doi.org/10.1086/523332

Tannock, G.W. (2001). Molecular assessment of intestinal microflora. American Journal of Clinical Nutrition, 73(2), 465S-470S. https://doi.org/10.1093/ ajcn/73.2.410s

Vaquero, I., Marcobal, Á. and Muñoz, R. (2004).Tannase activity by lactic acid bacteria isolated from grape must and wine. International Journal for Food Microbiology, 96(2), 199-204. https://doi.org/10.1016/j.ijfoodmicro.2004.04.004

Venkatesh Mannar, M.G. and Diosady, L.L. (1998). Double fortification of salt with iron and iodine. American Journal of Clinical Nutrition, 28, 13451401.

Wehr, H.M. and Frank, J.F. (2004). Standard Methods for the Examination of Dairy Products. $17^{\text {th }}$ ed. Washington, D.C.: APHA Press. https:// doi.org/10.2105/9780875530024

Wiczkowski, W., Topolska, J., Szawara-Nowak, D., Baczek, N., Majkowska, A. and Zielinski, H. (2016). Change of polyphenols during fermentation of buckwheat flour by lactic acid bacteria. $15^{\text {th }}$ International Conference on Food Processing and Technology, October 27-29, 2016, Rome, Italy. Journal Food Processing and Technology, 7, 12 (Suppl.), 101. https://doi.org/10.4172/21577110.C1.057

Wiegand, I., Hilpert, K. and Hancock, R.E.W. (2008). Agar and broth dilution methods to determine the minimal inhibitory concentration (MIC) on antimicrobial substances. Nature Protocols, 3(2), 163-175. https://doi.org/10.1038/nprot.2007.521

Willing, B. P., Pepin, D. M., Marcolla, C.S., Forgie, A.J. , Diether, N.E. and Bourrie, B.C.T. (2018). Bacterial resistance to antibiotic alternatives: a wolf in sheep's clothing? Animal Frontiers, 8(2),39-47. https://doi.org/10.1093/af/vfy003 